\title{
Characterization and Establishment of a Recombinase Polymerase Amplification Assay for Rapid Detection of Tomato Spotted Wilt Virus in Pepper
}

\section{Kaiqiang Hao}

Shenyang Agricultural University

\section{Ming Gu}

Shenyang Agricultural University

\section{Miaoren Yang}

Shenyang Agricultural University

\section{Xinran Gao}

Shenyang Agricultural University

\section{Zihao Xia}

Shenyang Agricultural University

\section{Mengnan An}

Shenyang Agricultural University

\section{Zhiping Wang}

Shenyang Agricultural University

Xiuxiang Zhao ( $\square$ zhaoxx0772@syau.edu.cn)

Shenyang Agricultural University https://orcid.org/0000-0002-9814-6256

\section{Yuanhua Wu}

Shenyang Agricultural University

\section{Research Article}

Keywords: Tomato spotted wilt virus (TSWV), polymerase amplification, rapid detection, pepper, plant viruses

Posted Date: November 15th, 2021

DOI: https://doi.org/10.21203/rs.3.rs-1030260/v1

License: (9) This work is licensed under a Creative Commons Attribution 4.0 International License. Read Full License 


\section{Abstract}

Tomato spotted wilt virus (TSWV) is one of the most economically destructive and scientifically challenging plant viruses, which has seriously affected the production of commercial crops. At present, there is no effective strategy to control this virus. Therefore, there is an urgent need for a rapid and simple method to detect TSWV, which is of great significance to prevent its spread. In this study, an isolate of TSWV (TSWV-LNTL) infecting pepper from Liaoning Province of northeast China was obtained. A phylogenetic tree based on neighbor-joining using coat protein (CP) gene was established. A rapid method for detecting TSWV by recombinase polymerase amplification (RPA) was established. The phylogenetic tree based on the nucleotide sequences of coat protein (CP) genes of different TSWV isolates showed that the genetic relationship of TSWV-LNTL was most closely related to that of TSWVLX-Lettuce-12 (Yunnan) and TSWV-TSHL (Shandong) isolates in China. It can be finished at $39^{\circ} \mathrm{C}$ for 20 min and then purified by heating at $65^{\circ} \mathrm{C}$ for $10 \mathrm{~min}$. The RPA primers were highly specific and no crossreactivity was detected with other selected viruses infecting pepper. The results of sensitivity test revealed that the detection limit of RPA is $1.0 \times 10^{3}$ copies/ $\mu \mathrm{L}$, which was tenfold lower than that of PCR method. In addition, the RPA method was successfully applied to detect TSWV in field samples. These results reported the occurrence of TSWV on crop in Liaoning Province of northeast China and demonstrated that the established RPA assay provided an effective molecular diagnostic tool for the accurate and rapid detection of TSWV to prevent its spread.

\section{Introduction}

Tomato spotted wilt virus (TSWV) is the type member of the genus Tospovirus in the family Bunyaviridae $[1,2]$. TSWV can infect more than 900 plant species that include numerous of crops, such as bean, lettuce, peanut, pepper, potato, tobacco, and tomato [3]. In nature, TSWV is transmitted mainly by several species of thrips [4]. The first description of the 'spotted wilt' disease of tomato occurred in 1915 in Australia [5]. Nowadays, TSWV has been one of the most economically destructive and scientifically challenging plant viruses [6].

In China, symptoms on tomato plants, resembling tomato spotted wilt disease, were first described in Sichuan Province in 1944 [7]. After that, with the spread of TSWV, it has been reported on many horticultural plants Yunnan, Guangzhou, Shandong, Beijing and Qinghai [8-12]. In northeast China, Liaoning Province is an important region of vegetable production, especially in winter. In June 2019 , the mosaic disease on Nasturtium (Tropaeolum majus L.) caused by TSWV was identified in Beiling Park in Shenyang City, Liaoning Province, China [13]. The spread of TSWV in northern China tends to increase, which will cause serious losses to vegetable production. Therefore, to establish a rapid, sensitive and specific method to detect TSWV is of great importance to the development of early monitoring, prevention, and effective control strategies.

At present, several methods have been used to detect TSWV in plant tissues, mainly including immunoelectron microscope (IEM), enzyme-linked immunosorbent assay (ELISA), reverse transcriptase- 
polymerase chain reaction (RT-PCR), real-time RT-PCR and reverse transcription loop-mediated isothermal amplification (RT-LAMP) [14-18]. However, these methods require appropriate training, technical expertise, or expensive and sophisticated thermal cycling equipment [19], which are time-consuming and cannot be used for TSWV detection in field samples.

Recombinase polymerase amplification (RPA) is an isothermal nucleic acid amplification technique, which considered to be a rapid, sensitive and economical method for molecular diagnosis [20]. In recent years, RPA has been developed rapidly in the detection of plant viruses [21]. Since the emergence of application of RPA to detect little cherry virus 2 (LChV2) [22], more and more plant viruses have been detected by RPA, especially in 2020, such as chilli veinal mottle virus (ChiVMV), milk vetch dwarf virus (MDV), piper yellow mottle virus (PYMoV), cardamom vein clearing virus (CdVCV), barley yellow dwarf virus (BYDV), cucurbit yellow stunting disorder virus (CYSDV) [23-28]. In this study, pepper leaves with suspected symptoms of TSWV were collected from Tieling city of Liaoning Province in 2020. The TSWVLNTL isolate was identified and analyzed. Moreover, we established a rapid and effective RPA method to detect TSWV, which laid the foundation of warning mechanism for prevention and control of TSWV.

\section{Materials And Methods}

\section{Sources of viral samples}

The pepper leaves with suspected symptoms of TSWV were collected from Tieling city of Liaoning Province in 2020. The positive TSWV Yunnan isolate was provided by Dr. Fenglong Wang (Key Laboratory of Tobacco Pest Monitoring Controlling \& Integrated Management, Tobacco Research Institute of Chinese Academy of Agricultural Sciences, Qingdao 266101, China), and tobacco mosaic virus (TMV), cucumber mosaic virus (CMV), pepper mild mottle virus (PMMoV), potato virus $Y$ (PVY) and ChiVMV were identified and maintained in our laboratory.

\section{Plant materials and virus inoculation}

The collected fresh leaves were homogenized with carborundum in $0.01 \mathrm{M}$ phosphate buffer $(\mathrm{pH} 7.0)$ at 1:10 (w/v) ratio. The pepper and peanut with vigorous growth at the 5-leaf stage grown in a growth chamber (day/night temperatures of $26^{\circ} \mathrm{C} / 22^{\circ} \mathrm{C}, \sim 60 \%$ relative humidity, 16 hours of light and 8 hours of dark light) were chosen to inoculate with TSWV on two leaves for each plant. After inoculation, the pepper and peanut plants were grown in the light culture room.

\section{RNA extraction, CDNA synthesis and PCR}

Total RNA was extracted from 100 mg of leaves using an Eastep ${ }^{T M}$ Super Total RNA Extraction Kit (Promega, Shanghai, China) following the manufacturers' instructions, followed by first-strand cDNA synthesis using $1 \mu \mathrm{g}$ of total RNA with the HiScript ${ }^{\circledR}$ III 1 st Strand cDNA Synthesis Kit (Vazyme, Nanjing, China). 
Conventional PCR was performed using the RPA primers. All conventional PCR reactions were conducted in $20 \mu \mathrm{L}$ volumes, containing $0.2 \mu \mathrm{M}$ of each forward and reverse primer, $10 \mathrm{ul} 2 \times$ Taq Master Mix (Dye Plus) (Vazyme, Nanjing, China), and $0.5 \mu \mathrm{L}$ template DNA. The PCR cycling conditions were as follows: $95^{\circ} \mathrm{C}$ for $3 \mathrm{~min}, 35$ cycles at $95^{\circ} \mathrm{C}$ for $15 \mathrm{~s}, 55^{\circ} \mathrm{C}$ for $15 \mathrm{~s}$, and $72^{\circ} \mathrm{C}$ for $20 \mathrm{~s}$, and a final incubation at $72^{\circ} \mathrm{C}$ for 5 min. The PCR products were visualized and verified using $1.5 \%$ agarose gel electrophoresis.

\section{The obtainment of TSWV-LNTL CP sequence}

According to the sequence of TSWV CP gene (GenBank Accession No. NC_002051.1), primers (TSWV$\mathrm{F} / \mathrm{R}$ ) were designed to detect TSWV in diseased pepper or peanut plants. The sequencing results were compared at the GenBank (https://www.ncbi.nlm.nih.gov/genbank/) by BLASTn, and the TSWV-YNHS isolate (GenBank Accession No. MN365037.1) with 99.54\% similarity was selected to design primers (TSWV-CPF/R) to amplify the full-length CP gene of TSWV-LNTL. The target fragment was ligated into pEASY-T1 vector (TransGen Biotech, Beijing, China) to construct pEASY-T1-CP plasmid. After sequencing, the sequence of TSWV-LNTL complete CP gene with 777 bp in length was obtained and deposited in the GenBank database with accession number MZ005203. The sequences of the primers were listed in Table 1.

Table 1

The information of primers used in this study.

\begin{tabular}{|c|c|c|c|}
\hline Primers & Sequences $\left(5^{\prime}-3^{\prime}\right)$ & Length (nt) & Product size (bp) \\
\hline TSWV-F & GCATTAGGATTGCTGGAGC & 19 & \multirow[t]{2}{*}{434} \\
\hline TSWV-R & ACTTCAGACAGGATTGGAGC & 20 & \\
\hline TSWV-CPF & TTAAGCAAGTTCTGCAAGTTTTGCC & 25 & \multirow[t]{2}{*}{777} \\
\hline TSWV-CPR & ATGTCTAAGGTTAAGCTCACTAAGG & 25 & \\
\hline RPA- TSWV13F & ATAGCAGCATACTCTTTCCCTTTCTTCAC & 29 & \multirow[t]{2}{*}{116} \\
\hline RPA- TSWV1R & GATCCAAAGAAGTATGACACCAGGGAAGC & 29 & \\
\hline RPA-TSWV2F & AGCAGCATACTCTTTCCСTTTCTTCACCT & 29 & \multirow[t]{2}{*}{104} \\
\hline RPA- TSWV2R & AGTATGACACCAGGGAAGCCTTAGGAAAA & 29 & \\
\hline RPA- TSWV13F & ATAGCAGCATACTCTTTCCCTTTCTTCAC & 29 & \multirow[t]{2}{*}{282} \\
\hline RPA-TSWV3R & СССTCTGATTCAAGCCTATGGATTACCTCT & 30 & \\
\hline
\end{tabular}

\section{Phylogenetic tree construction}

In order to analyze the phylogenetic relationship and taxonomic status of TSWV-LNTL isolate, the CP nucleotide sequence was compared with that of other eighteen TSWV isolates (Accession No. KX185153.1, KP330471.1, FR693053.1, AB910533.1, KX579057.1, MK524182.1, EF195227.1, 
MH172161.1, FR693048.1, KC494486.1, KY923204.2, KM37914.1, HQ406934.1, GU369727.1, AF306490.1, HQ267709.1, JX468079.1 and FR603109.1) deposited in GenBank database. The sequence of tomato chlorotic spot virus (KJ399303.1) was used as outgroup member (Table 2). The phylogenetic tree of TSWV CP nucleotide sequence was constructed by adjacency method (Neighbor-joining) using MEGA7.0 software [29]. The phylogenetic tree was constructed using 2000 bootstrap repeat sequences as matrices in the phylogenetic process of the adjacent connections [23]. 
Table 2

The genomic sequence identity between TSWV-LNTL and other 18 TSWV isolates.

\begin{tabular}{|c|c|c|c|c|c|}
\hline $\begin{array}{l}\text { Virus } \\
\text { Abbreviation }\end{array}$ & $\begin{array}{l}\text { GenBank } \\
\text { Number }\end{array}$ & County & Host & $\begin{array}{l}\text { Size } \\
\text { (nt) }\end{array}$ & $\begin{array}{l}\text { Nucleotide } \\
\text { Identity (\%) }\end{array}$ \\
\hline $\begin{array}{l}\text { TSWV-LX- } \\
\text { Lettuce-12 }\end{array}$ & KP330471.1 & China & lactuca sativa & 777 & $99.74 \%$ \\
\hline TSWV-TSHL & KX185153.1 & China & Cucurbita moschata & 777 & $99.61 \%$ \\
\hline $\begin{array}{l}\text { TSWV- } \\
\text { France81 }\end{array}$ & FR693053.1 & France & Capsicum & 774 & $98.45 \%$ \\
\hline TSWV-pA7 & MK524182.1 & Argentina & pepper & 777 & $98.32 \%$ \\
\hline TSWV-NA3 & KX579057.1 & Argentina & Alstroemeria & 777 & $97.81 \%$ \\
\hline TSWV-AT1 & AB910533.1 & South Korea & Brugmansia sp. & 777 & $97.42 \%$ \\
\hline $\begin{array}{l}\text { TSWV- } \\
\text { CHM6 }\end{array}$ & FR693048.1 & Italy & $\begin{array}{l}\text { Chrysanthemum } \\
\text { murifolium }\end{array}$ & 774 & $96.90 \%$ \\
\hline $\begin{array}{l}\text { TSWV- } \\
\text { PFR05 }\end{array}$ & KC494486.1 & New Zealand & $\begin{array}{l}\text { Solanum } \\
\text { lycopersicum }\end{array}$ & 777 & $96.78 \%$ \\
\hline $\begin{array}{l}\text { TSWV-SC- } \\
\text { NRB }\end{array}$ & KM379142.1 & Turkey & Capsicum annuum $L$ & 777 & $96.77 \%$ \\
\hline TSWV-KAIxe & EF195227.1 & South Korea & Ixeris chinensis & 777 & $96.77 \%$ \\
\hline $\begin{array}{l}\text { TSWV- } \\
\text { Gneung }\end{array}$ & HQ267709.1 & South Korea & Capsicum annuum & 777 & $96.65 \%$ \\
\hline $\begin{array}{l}\text { TSWV-160- } \\
12\end{array}$ & JX468079.1 & $\begin{array}{l}\text { Bosnia and } \\
\text { Herzegovina }\end{array}$ & $\begin{array}{l}\text { Sinningia speciosa } \\
\text { (gloxinia) }\end{array}$ & 702 & $96.58 \%$ \\
\hline $\begin{array}{l}\text { TSWV- } \\
\text { Hawaiian }\end{array}$ & AF306490.1 & USA & -- & 859 & $96.36 \%$ \\
\hline TSWV-AART & MH172161.1 & Pakistan & tomato & 777 & $96.26 \%$ \\
\hline $\begin{array}{l}\text { TSWV-VE- } \\
225\end{array}$ & GU369727.1 & Brazil & pepper & 777 & $96.00 \%$ \\
\hline TSWV-P176 & FR693109.1 & Spain & Capsicum & 774 & $95.99 \%$ \\
\hline $\begin{array}{l}\text { TSWV-NC- } \\
16\end{array}$ & KY923204.2 & Iran & -- & 776 & $95.74 \%$ \\
\hline $\begin{array}{l}\text { TSWV-McC- } \\
\text { SumR }\end{array}$ & HQ406934.1 & USA & $\begin{array}{l}\text { Arachis hypogaea } \\
\text { cultivar McCloud }\end{array}$ & 777 & $95.50 \%$ \\
\hline TCSV-DRF1 & KJ399303.1 & $\begin{array}{l}\text { Dominican Republic: } \\
\text { Laguana Bajo }\end{array}$ & $\begin{array}{l}\text { Bean cultivar } \\
\text { Vainita-Larga }\end{array}$ & 777 & $77.61 \%$ \\
\hline
\end{tabular}




\section{RPA reaction}

Three pairs of specific primers for RPA detection were designed according to the conserved regions of TSWV CP sequences (Table 1). The RPA assays were performed in a total volume of $50 \mu \mathrm{L}$ using a TwistAmp Basic ${ }^{\circledR}$ Kit (TwistDX Ltd., Cambridge, United Kingdom) following the manufacturers' instructions. Each $50 \mu \mathrm{L}$ reaction contained $29.5 \mu \mathrm{L}$ of a rehydration buffer, $2.4 \mu \mathrm{L}$ of each primer (10 $\mu \mathrm{M}), 2.5 \mu \mathrm{L}$ of magnesium acetate $(280 \mathrm{mM}), 11.2 \mu \mathrm{L}$ of nuclease-free water, and $2.0 \mu \mathrm{L}$ of cDNAs or plasmids. All reagents, except for MgOAc, were prepared in a master mix and added to a reaction tube containing a dried enzyme pellet. The RPA reaction was initiated by adding $280 \mathrm{mM} \mathrm{MgOAc}$, then incubated at $39^{\circ} \mathrm{C}$ for $20 \mathrm{~min}$.

After the RPA reaction, the enzyme proteins are combined with DNA to affect agarose gel electrophoresis. Therefore, DNA products need to be purified or other processing $[20,30]$. In order to facilitate the visualization of RPA products, we processed the DNA products of RPA in a water bath at $65^{\circ} \mathrm{C}$ for $10 \mathrm{~min}$, a method previously verified in our laboratory [31]. After that, the purified DNA was electrophoresed on 1.5 $\%$ agarose gel.

\section{Specificity and sensitivity analysis of the RPA assay}

To evaluate the specificity of the established RPA assay, we tested six viruses infecting pepper, including TSWV, TMV, CMV, PMMoV, ChiVMV and PVY. Tissues from buffer-inoculated healthy pepper plants were used as negative controls in this study. To assess the sensitivity of the RPA primers, the pEASY-T1-CP plasmid was used, which was diluted to $1.0-1.0 \times 10^{9}$ copies $/ \mu \mathrm{L}$ as template for RPA and PCR to evaluate the detection limit, respectively. Plasmid copy number was calculated using the following formula: Number of copies $=\left(\right.$ amount $\left.[\mathrm{ng}] * 6.022 \times 10^{23}\right) /\left(\right.$ length [bp] $* 1 \times 10^{9 * 660)}$ [32] .

\section{Optimization of RPA reaction time}

To optimize the reaction time, the RPA assays were reacted for $10,20,30,40,50,60$ min using cDNAs of TSWV-infected pepper plants as template, respectively. The DNA products of RPA were processed in a water bath at $65^{\circ} \mathrm{C}$ for $10 \mathrm{~min}$ and then visualized in $1.5 \%$ agarose gels through electrophoresis and ethidium bromide staining.

\section{Feasibility tests of RPA assay for field samples}

The feasibility of RPA method for the detection of TSWV in field samples was investigated. Sample collection, synthetic cDNA and RPA tests were performed as described above. In addition, these 10 field samples were also detected by conventional PCR. Pepper plants inoculated by TSWV-LNTL and buffer were used as positive and negative controls, respectively.

\section{Results}




\section{Identification of TSWV infecting pepper plants in Liaoning Province of China}

During the investigation of viral diseases on pepper in Tieling city of Liaoning Province in 2020, leaf samples with chlorosis, mottle, yellowing, and malformation symptoms were collected from field-grown pepper plants (Fig. 1A). To determine the virus causing pepper disease, the TSWV detection primers (TSWV-F/R) were used to detect the collected pepper sample by RT-PCR. The results showed that the specific band of about 435 bp were amplified in pepper sample. The nucleotide sequences of PCR products were obtained through cloning and sequencing, which were then aligned by BLASTn in GenBank database. The results revealed that the sequences had over $99 \%$ homology with that of TSWV.

To explore the pathogenicity of the putative TSWV, the crude extract of collected samples was mechanically inoculated onto different host plants. After twenty days post inoculation, the symptoms of chlorosis and yellowing were shown in all tested pepper and peanut plants (Fig. 1A). Moreover, the TSWV detection primers (TSWV-F/R) were used to detect the inoculated pepper and peanut samples by RT-PCR. The results showed that the specific bands of about $435 \mathrm{bp}$ were obtained in the inoculated samples as that in field-collected pepper plants (Fig. 1B). Therefore, we determined that the symptomatic pepper samples were infected by TSWV (named TSWV-LNTL).

\section{Phylogenetic analysis of TSWV-LNTL}

To analyze the phylogenetic relationship, the complete CP sequence of TSWV-LNTL was obtained by RTPCR using TSWV-CPF/R primers. The results showed that the nucleotide homology was 95.50 99.74\% between TSWV-LNTL and other selected eighteen isolates. Notably, the nucleotide sequence identity values between TSWV-LNTL and a Yunnan isolate TSWV-LX-Lettuce-12 from Lactuca sativa and a Shandong isolate TSWV-TSHL from Cucurbita moschata were the highest $(99.74 \%$ and $99.61 \%$, respectively) (Table 2). The identity values were $97.42 \sim 98.45 \%$ with the TSWV isolates from France, South Korea and Argentina India (Table 2). The nucleotide-based neighbor-joining phylogenetic analysis showed that the isolates of TSWV-LNTL, TSWV-LX-Lettuce-12 and TSWV-TSHL were clustered in one branch (Fig. 2), suggesting that TSWV-LNTL had the closest relationship with the isolates of TSWV-LXLettuce-12 and TSWV-TSHL, consistent with the result based on identity value of the nucleotide sequence. These results indicated that the possible source of TSWV-LNTL came from the epidemic virus in China.

\section{Specificity of the RPA assay}

To obtain a better amplified result, three pairs of RPA primers for TSWV detection were designed based on conserved regions of CP sequences (Table 1). In the RPA results, only RPA-TSWV13F/3R could amplify bright and specific bands in both TSWV-LNTL and TSWV Yunnan isolates (Fig. 3). To evaluate the specificity of primers RPA-TSWV13F/3R, we tested the TSWV-, TMV-, CMV-, PMMoV-, ChiVMV-, or PVYinfected pepper leaf tissues. The results showed that only one clear DNA band of $\sim 280 \mathrm{bp}$ in length was 
visualized in the gels under the UV light from the TSWV-infected pepper leaf tissues (Fig. 4). This finding suggested that the primers of RPA method developed in this study for TSWV detection were specific.

\section{Optimization of RPA reaction time}

To optimize the RPA reaction time, the assays were reacted for $10,20,30,40,50,60$ min using cDNAs of TSWV-infected pepper plants as template. Analysis through densitometry revealed that the concentration of DNA band after 20 min or more time reaction was almost two-fold higher than that after 10 min reaction (Fig. 5). In consideration of effectiveness for TSWV detection, we selected 20 minutes as RPA reaction time in this study.

\section{Sensitivity detection of RPA}

In order to determine the sensitivity of the RPA assay, a series of 10 -fold dilutions from $1.0 \times 10^{9}$ to $1.0 \times 10^{0}$ copies/ $\mu \mathrm{L}$ of pEASY-T1-CP plasmids were used as template for RPA and PCR assays, respectively. Results showed that TSWV was detected in the plasmids diluted up to $1.0 \times 10^{3} \mathrm{copies} / \mu \mathrm{L}$ by RPA, which was about ten-fold more sensitive than that detected by PCR (up to $1.0 \times 10^{4} \mathrm{copies} / \mu \mathrm{L}$ ) (Fig. 6). This result indicated that the RPA assay was more sensitive than PCR assay for TSWV detection, based on the DNA band intensity in gels.

\section{Application of RPA assay for TSWV detection in field- collected samples}

To evaluate the feasibility of RPA method for TSWV detection in the field, 11 samples with TSWV or virallike symptoms collected from Shenyang, Tieling and Huludao of Liaoning Province were tested by RPA and PCR assays, respectively (Supplementary Table 1). The results showed that TSWV was detected in three plant samples from Shenyang and Tieling by RPA and PCR methods (Fig. 7). These results demonstrated that the established RPA assay was a rapid and sensitive method for TSWV detection, and could be successfully applied in the field-collected samples.

\section{Discussion}

TSWV causes severe yield losses by producing less valuable or unmarketable plants, fruits or flowers in many economically important crops [33]. In the investigation of plant viral diseases in 2020, we found diseased pepper plants infected with TSWV in Tieling city of Liaoning Province (Fig. 1). Liaoning Province is an important vegetable production base in northeast China. The infection of TSWV is expected to have a great impact on the production of commercial crops in this area. In 2020, TSWV were first reported on nasturtium in Dongling Park of Shenyang, Liaoning Province [13]. Moreover, we also detected TSWV in pepper and peanut plants collected from Shenyang city (Fig. 7). These results indicated that TSWV has been a serious threat on vegetables in Liaoning Province. By constructing the phylogenetic tree of TSWV-LNTL, we found that TSWV-LNTL was closely related to other isolates in China (Fig. 2). We speculated that the TSWV in Liaoning Province might come from vegetables or seedlings infected TSWV by the transportation from other epidemic areas in China. 
As an important isothermal amplification technology, RPA has attracted more and more attention in recent years, especially in virus detection [21]. In this work, the RPA method was successfully established to detect TSWV, which could be completed in $20 \mathrm{~min}$. In addition, RPA amplification was carried out at $39^{\circ} \mathrm{C}$ and purified at $65^{\circ} \mathrm{C}$, all of which could be performed under the condition of heating in a water bath pot, without the need for trained personnel and expensive equipment or procedures, which greatly increased the number of tests.

The difficulty in developing RPA is to obtain highly specific RPA primers [34]. We designed the primers of RPA followed the principles provided by the TwistAmp Basic ${ }^{\circledR}$ Kit (TwistDX Ltd., Cambridge, United Kingdom). Briefly, the principles were as follows: 1 ) the length of the primer is 30-35 nt. 2) long tracks of guanines at the 5 'end (first 35 nucleotides) should be avoided, while cytidines (and perhaps in general pyrimidines) may be beneficial, possibly because this encourages the formation of recombinase filaments. In previous studies, PCR analysis of CP gene against TSWV has been developed and widely used [35]. In this study, TSWV CP gene was used for PCR and RPA primer design and screening.

In the sensitivity test, the detection limit of RPA reaction was $10^{3}$ copies / $\mu \mathrm{L}$ of plasmid DNA, which was about 10 times higher than that of PCR (Fig. 6). Previous studies have confirmed that the sensitivity of RPA was the same as that of traditional real-time PCR analysis, or more sensitive than traditional PCR and LAMP assays $[23,36]$.

Compared to conventional and real-time PCR assays, the RPA assay does not require sophisticated equipment or electricity supply to perform the temperature changes required for DNA amplification. Therefore, RPA is a promising method for the diagnosis of plant pathogens [37]. In addition, further tests were also carried out to verify the diagnostic effectiveness of the RPA using field-collected samples by comparison with traditional PCR (Fig. 7). Therefore, RPA method is a simple and rapid alternative method for molecular diagnosis of TSWV in field-collected samples.

\section{Conclusions}

In conclusion, an isolate of TSWV (TSWV-LNTL) infecting pepper from Liaoning Province of northeast China was obtained. The genetic relationship between TSWV-LNTL and other isolates in China were relatively close. A RT-RPA method for detecting TSWV was established, which had the advantages of high specificity, high sensitivity, fast, simple equipment, strong practicability and so on. In a word, these characteristics make RPA assay a promising molecular diagnostic tool for accurate and rapid detection of TSWV.

\section{Declarations}

\section{Acknowledgements}

This research was funded by the High-tech R\&D Program of Liaoning (2019JH2/10200012). 


\section{Compliance with ethical standards}

\section{Conflict of interest}

The authors declare no conflict of interest

\section{References}

1. Moyer J (1999) Tospoviruses (Bunyaviridae). In 'Encyclopaedia of Virology'.(Eds A Granoff, R Webster) pp. In.: Academic Press: San Diego 1803-1807.

2. Tsompana M , Abad J, Purugganan M, Moyer J (2005) The molecular population genetics of the tomato spotted wilt virus (TSWV) genome. Molecular Ecology 14(1), 53-66.

3. Pappu H (2008) Tomato spotted wilt virus. Encyclopedia of Virology. 3rd ed. Elsevier Ltd 133-138.

4. Rotenberg D, Jacobson A, Schneweis D, Whitfield A (2015) Thrips transmission of tospoviruses. Current Opinion in Virology 15: 80-89.

5. Brittlebank C (1919) Tomato diseases. Journal of the Department of Agriculture in Victoria 17, 13481352.

6. Scholthof K, Adkins S, Czosnek H, Palukaitis P, Jacquot E., Hohn T, Hohn B, Saunders K, Candresse T, Ahlquist P, Hemenway C, Foster G (2011) Top 10 plant viruses in molecular plant pathology. Molecular Plant Pathology 12, 938-954.

7. Su D, Yuan X, Xie Y, Wang S, Ding H (1987) Tomato spotted wilt virus in tomato in Chengdu and Dukou. Acta Phytopathologica Sinica 4, 22.

8. Jiang L, Huang Y, Sun L, Wang B, Zhu M, Li J, Huang C, Liu Y, Li F, Liu Y, Dong J, Zhang Z, Tao X (2017) Occurrence and diversity of tomato spotted wilt virus isolates breaking the TSWV resistance gene of Capsicum Chinense in Yunnan, southwest China. Plant Pathology 66 (6), 980-989.

9. Liu Y, Li Y, Wu Z, Rao X (2010) Identification of tomato spotted wilt virus on pepper in Guangzhou. Acta Phytophylacica Sinica 4.

10. Sun X, Gao L, Wang S, Wang C, Yang Y, Zhu X (2016) First report of tomato spotted wilt virus infecting pumpkin in China. Journal of plant pathology 98,3 .

11. Li F, Wu Q, Xu B, Xie W, Wang S, Zhang Y (2012) Tomato spotted wilt virus was identified in Beijing. Plant Protection 38 (6), 186-188.

12. Wu S, Tu L, Xian W, Yan G, Gao D, Ji Y, Tao X, Zhou Y, Guo Q, Ji Y (2020) Detection and identification of tomato spotted wilt tospovirus on pepper from Qinghai Province. Acta Horticulturae Sinica 47 (7), 1391.

13. Yu M, Yang C, Wang J, Hou Q, Zhang S, Cao M (2021) First report of tomato spotted wilt virus (TSWV) isolated from nasturtium (Tropaeolum majus L.) with a serious leaf mosaic disease in China. Plant Disease 105 (3), 716-716.

14. Kitajima E, Resende R, de Âvila A, Goldbach R, Peters D (1992) Immuno-electron microscopical detection of tomato spotted wilt virus and its nucleocapsids in crude plant extracts. Journal of 
Virological Methods 38, 313-322.

15. Adam G, Lesemann D, Vetten H (1991) Monoclonal antibodies against tomato spotted wilt virus: characterisation and application. Annals of Applied Biology 118, 87-104.

16. Roberts C, Dietzgen R, Heelan L, Maclean D (2000) Real-time RT-PCR fluorescent detection of tomato spotted wilt virus. Journal of Virological Methods 88, 1-8.

17. Fukuta S, Ohishi K, Yoshida K, Mizukami Y, Ishida A, Kanbe M (2004) Development of immunocapture reverse transcription loop-mediated isothermal amplification for the detection of tomato spotted wilt virus from chrysanthemum. Journal of Virological Methods 121, 49-55.

18. Garland S, Sharman M, Persley D, McGrath D (2005) The development of an improved PCR-based marker system for Sw-5, an important TSWV resistance gene of tomato. Australian Journal of Agricultural Research 56, 285-289.

19. Lau H, Botella J (2017) Advanced DNA-based point-of-care diagnostic methods for plant diseases detection. Frontiers in Plant Science 8, 2016.

20. Piepenburg O, Williams C, Stemple D, Armes N (2006) DNA detection using recombination proteins. PLoS Biology 4, e204.

21. Babu B, Ochoa-Corona FM Paret ML (2018) Recombinase polymerase amplification applied to plant virus detection and potential implications. Analytical Biochemistry 546, 72-77.

22. Mekuria T, Zhang S, Eastwell K (2014) Rapid and sensitive detection of little cherry virus 2 using isothermal reverse transcription-recombinase polymerase amplification. Journal of Virological Methods 205, 24-30.

23. Jiao Y, Xu C, Li J, Gu Y, Xia C, Xie Q, Xie Y, An M, Xia Z, Wu Y (2020) Characterization and a RT-RPA assay for rapid detection of chilli veinal mottle virus (ChiVMV) in tobacco. Virology Journal 17, 33.

24. Cao Y, Yan D, Wu X, Chen Z, Lai Y, Lv L, Yan F, Chen J, Zheng H, Song, X (2020) Rapid and visual detection of milk vetch dwarf virus using recombinase polymerase amplification combined with lateral flow strips. Virology Journal 17, 102.

25. Mohandas A, Bhat A (2020) Recombinase polymerase amplification assay for the detection of piper yellow mottle virus infecting black pepper. Virus disease 31, 38-44.

26. Naveen K, Bhat A (2020) Reverse transcriptase loop-mediated isothermal amplification and reverse transcriptase recombinase amplification assays for rapid and sensitive detection of cardamom vein clearing virus. 3 Biotech 10, 1-9.

27. Kim N, Kim S, Jeong R (2020) Reverse transcription recombinase polymerase amplification assay for rapid and sensitive detection of barley yellow dwarf virus in oat. The Plant Pathology Journal 36, 497-502.

28. Kalischuk M, Roberts P, Paret M (2020) A rapid fluorescence-based real-time isothermal assay for the detection of Cucurbit yellow stunting disorder virus in squash and watermelon plants. Molecular and Cellular Probes 53, 101613. 
29. Kumar S, Stecher G, Tamura K (2016) MEGA7: molecular evolutionary genetics analysis version 7.0 for bigger datasets. Molecular Biology and Evolution 33, 1870-1874.

30. Kersting S, Rausch V, Bier F, von Nickisch-Rosenegk M (2014) Multiplex isothermal solid-phase recombinase polymerase amplification for the specific and fast DNA-based detection of three bacterial pathogens. Microchimica Acta 181, 1715-1723.

31. Jiao Y, Jiang J, Wu Y, Xia Z (2019) Rapid detection of cucumber green mottle mosaic virus in watermelon through a recombinase polymerase amplification assay. Journal of Virological Methods $270,146-149$.

32. Johnson S, Carlson E, Pappagianis D (2015) Determination of ribosomal DNA copy number and comparison among strains of Coccidioides. Mycopathologia 179, 45-51.

33. Ramkat R, Wangai A, Ouma J, Rapando P, Lelgut D (2006) Effect of mechanical inoculation of tomato spotted wilt tospovirus disease on disease severity and yield of greenhouse raised tomatoes. Asian Journal of Plant Sciences 5, 607-612.

34. Ju Y, Li C, Shen P, Wan N, Han W, Pan Y (2020) Rapid and visual detection of Verticillium dahliae using recombinase polymerase amplification combined with lateral flow dipstick. Crop Protection 136, 105226.

35. Boonham N, Smith P, Walsh K, Tame J, Morris J, Spenc N, Bennison J, Barker I (2002) The detection of Tomato spotted wilt virus (TSWV) in individual thrips using real time fluorescent RT-PCR (TaqMan). Journal of Virological Methods 101, 37-48.

36. Karakkat B, Hockemeyer K, Franchett M, Olson M, Mullenberg C, Koch P (2018) Detection of rootinfecting fungi on cool-season turfgrasses using loop-mediated isothermal amplification and recombinase polymerase amplification. Journal of Microbiological Methods 151, 90-98.

37. Lau H, Botella J (2017) Advanced DNA-based point-of-care diagnostic methods for plant diseases detection. Frontiers in plant science 8, 2016.

\section{Figures}



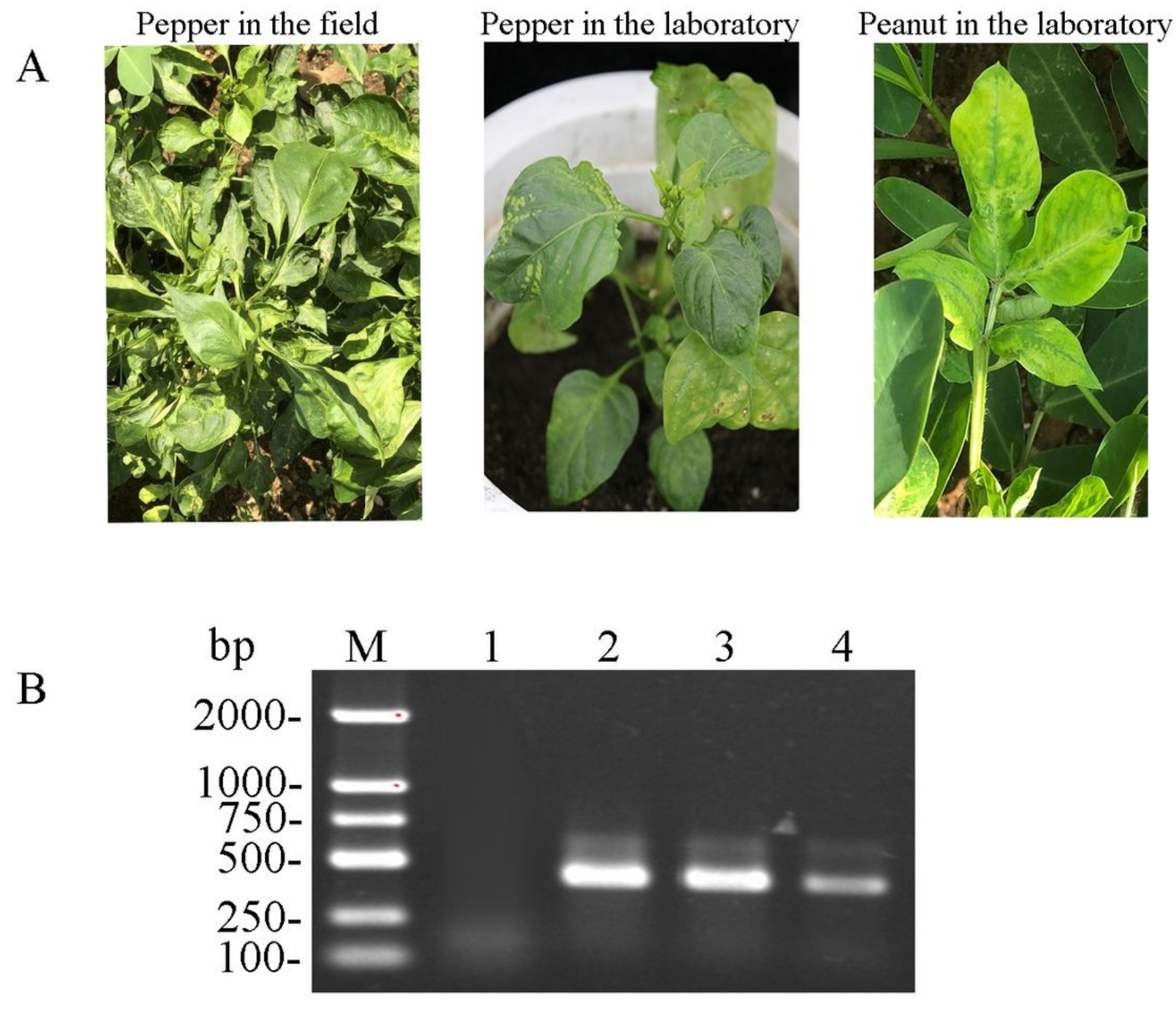

\section{Figure 1}

Identification of TSWV infecting pepper plants. A: Symptoms of diseased pepper and peanut plants in the field or laboratory after inoculation, B: TSWV detection by RT-PCR method. Lane M, Trans2K DNA marker; lane 1, double-distilled water; lane 2, diseased pepper in the field; lane 3, diseased pepper in the laboratory after inoculation with TSWV; lane 4, diseased peanut in the laboratory after inoculation with TSWV. 


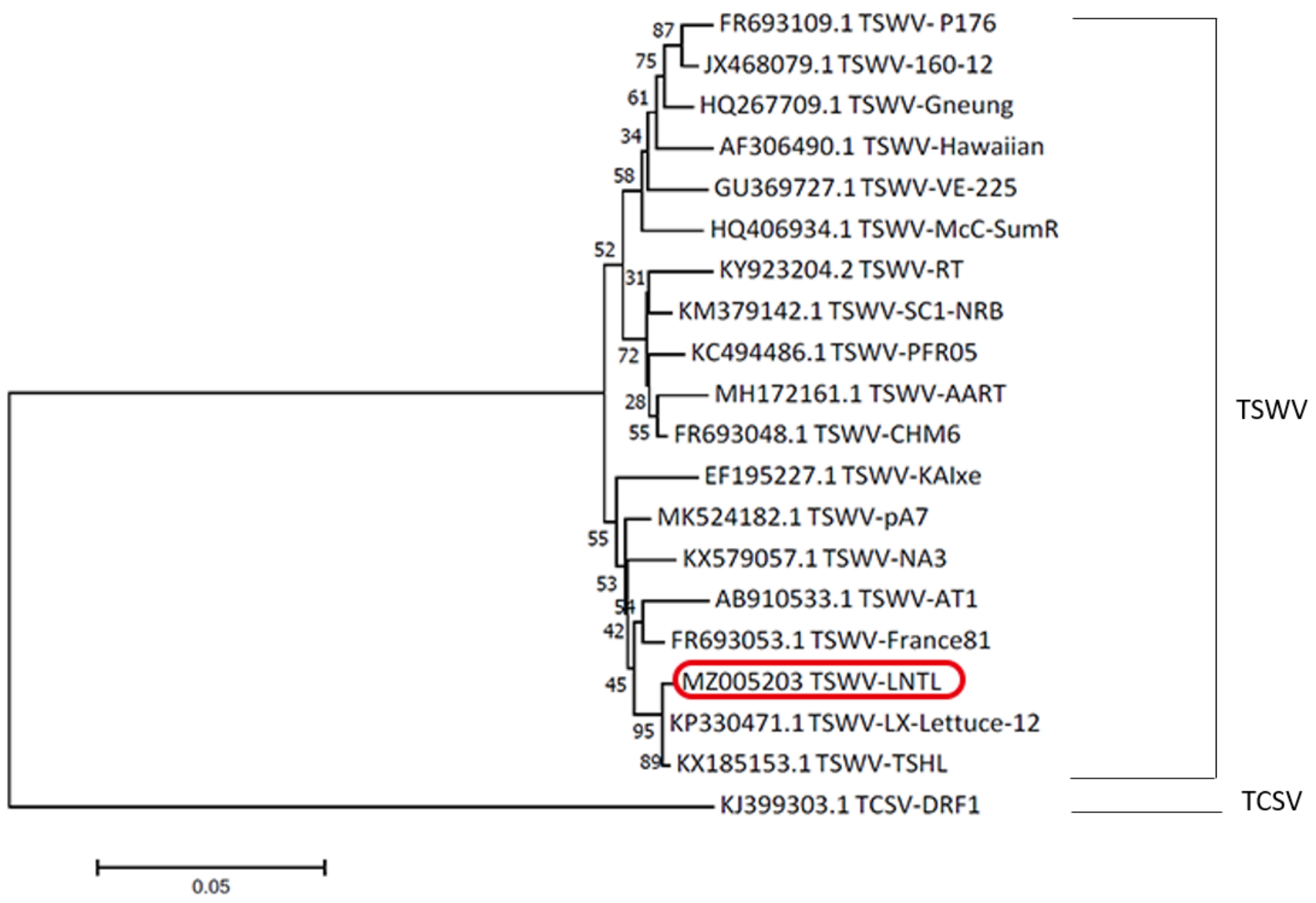

Figure 2

Phylogenetic analysis of 19 TSWV isolates based on CP nucleotide sequence. The phylogenetic trees were generated using the neighbor-joining method by MEGA7 software. The percentage of replicate trees in which the associated taxa clustered together in the bootstrap test (1000 replicates) was shown next to the branches. 


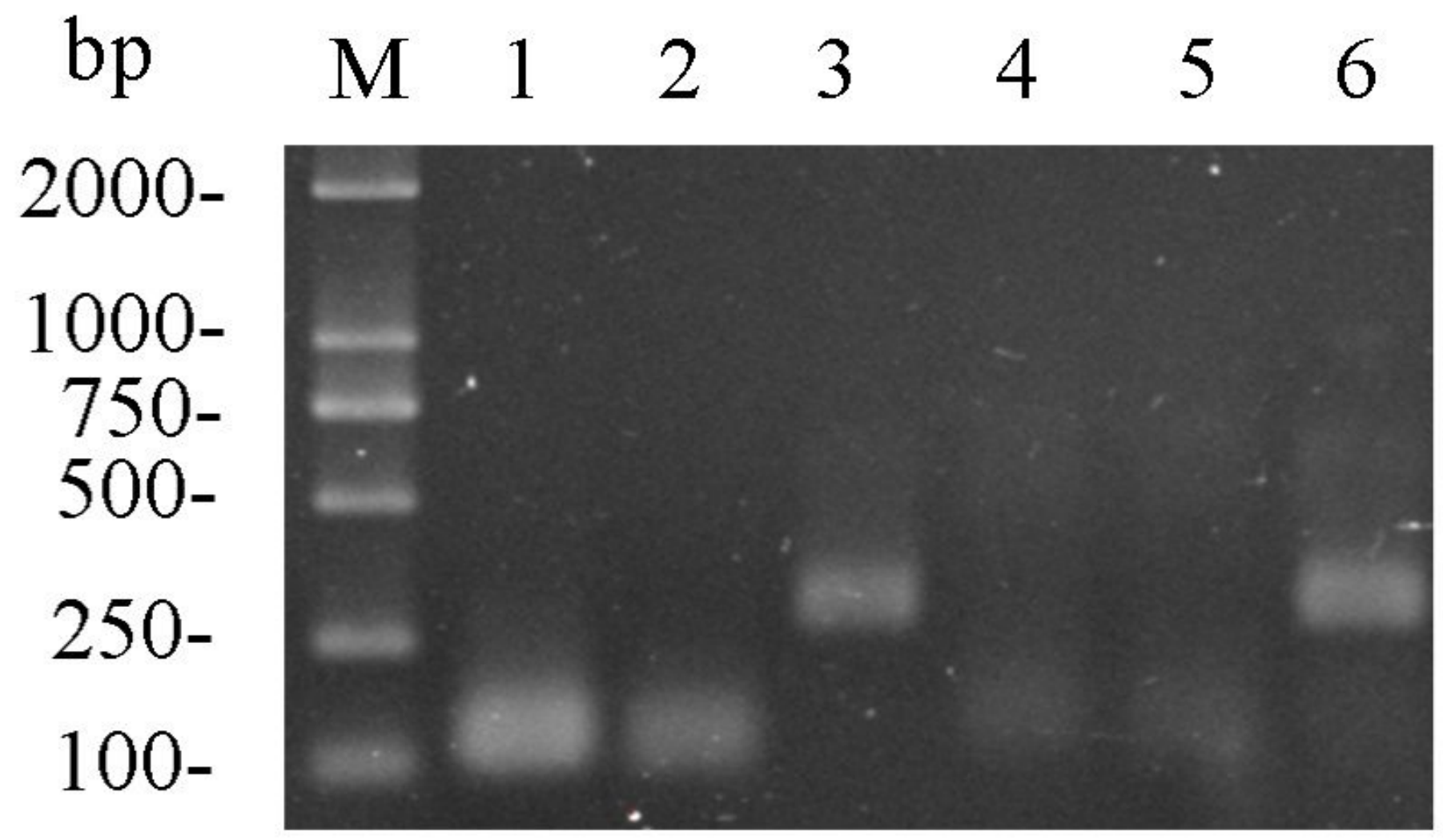

Figure 3

Tests of three pairs of primers by RPA. Three pairs of primers were used to amplify the cDNAs of pepper plants infected with TSWV-LNTL (lane 1-3) and tobacco plants infected with TSWV Yunnan isolate (lane 4-6). Lane M, Trans2K DNA marker; lane 1 and 4, primers RPA-TSWV13F/ RPA-TSWV1R; lane 2 and 5, primers RPA-TSWV2F/ RPA-TSWV2R; lane 3 and 6, primers RPA-TSWV13F/RPA-TSWV3R.

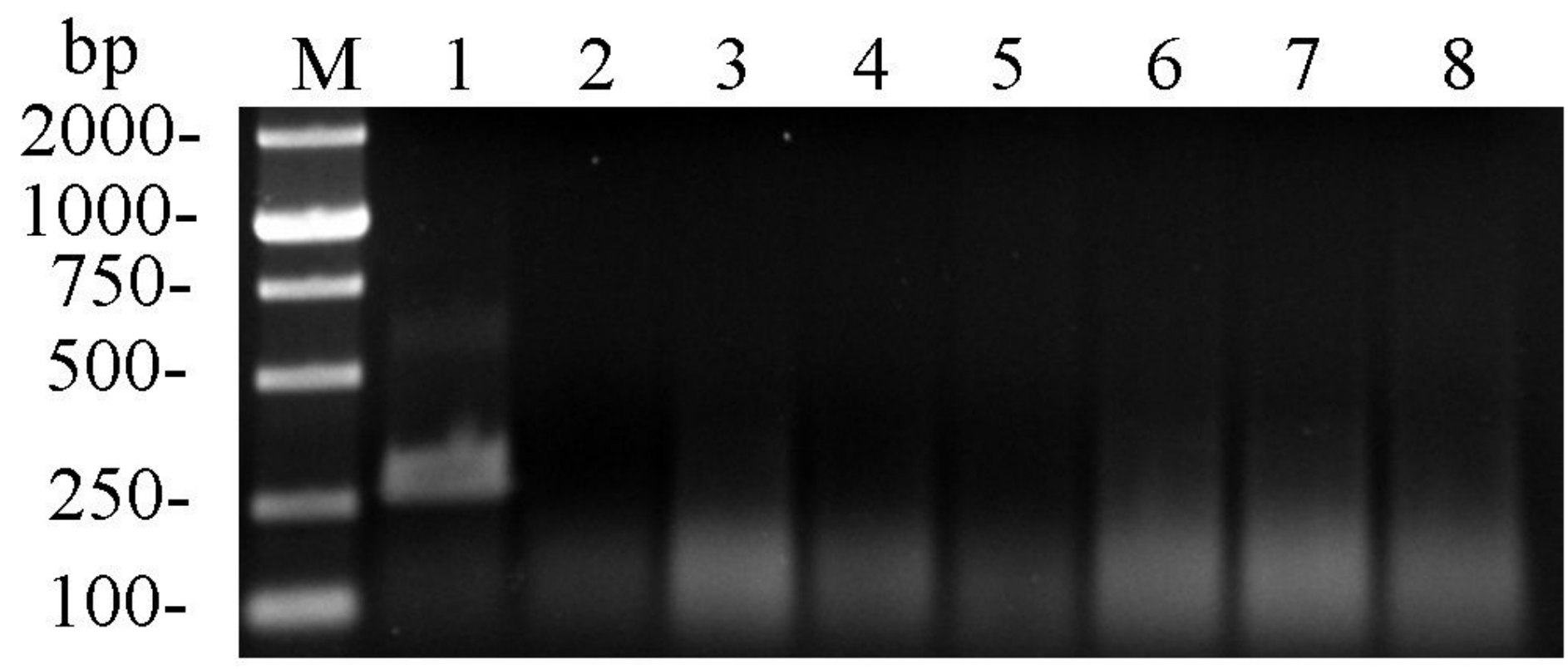


Figure 4

Specificity of RPA assay. Lane M, Trans2K DNA marker; lane 1, TSWV-LNTL-infected pepper plants; lane 2, ddH2O; lane 3, healthy pepper leaf tissues; lane 4-8, TMV-, CMV-, PMMoV-, ChiVMV- and PVY-infected pepper plants, respectively.

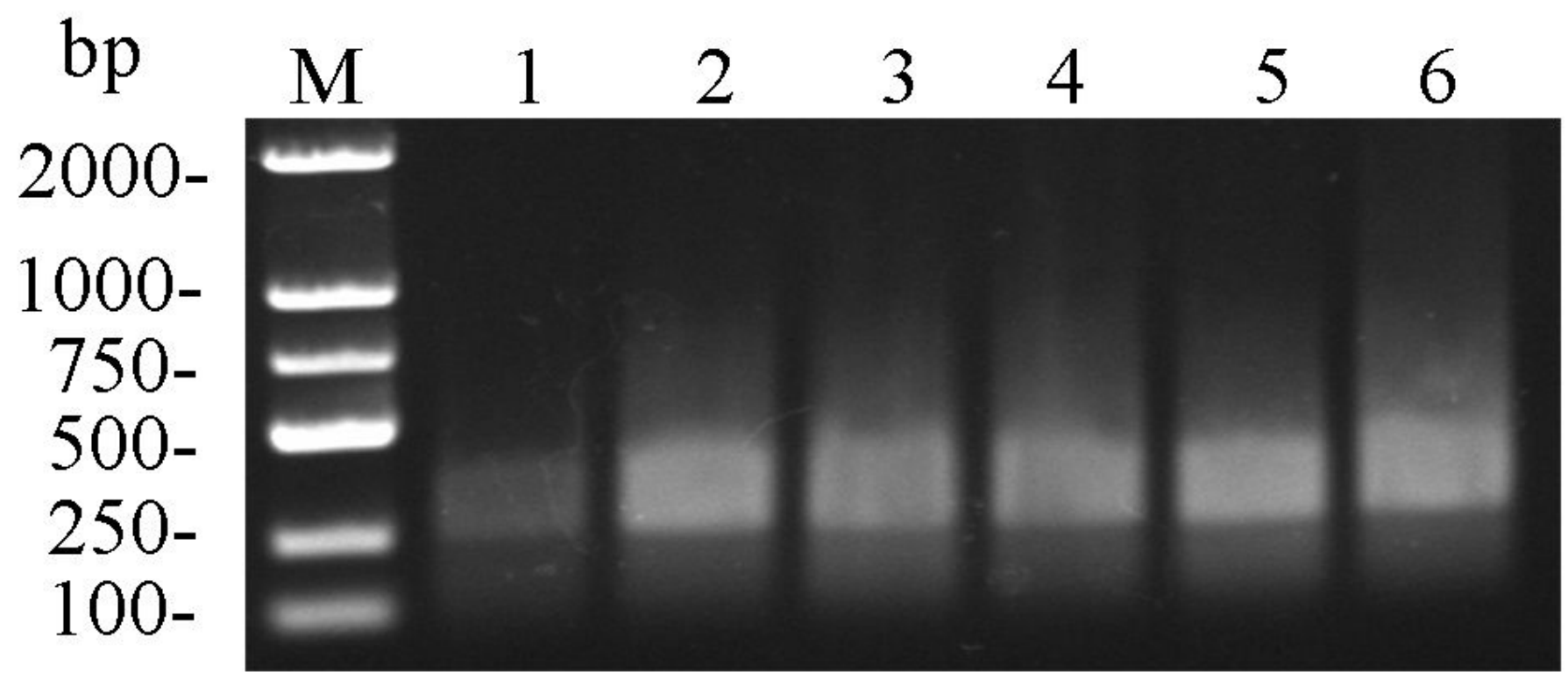

\section{Figure 5}

Optimization of RPA reaction time. Lane M, Trans2K DNA marker; lanes 1-6, DNA products amplified by RPA for $10,20,30,40,50$ and 60 min, respectively. 


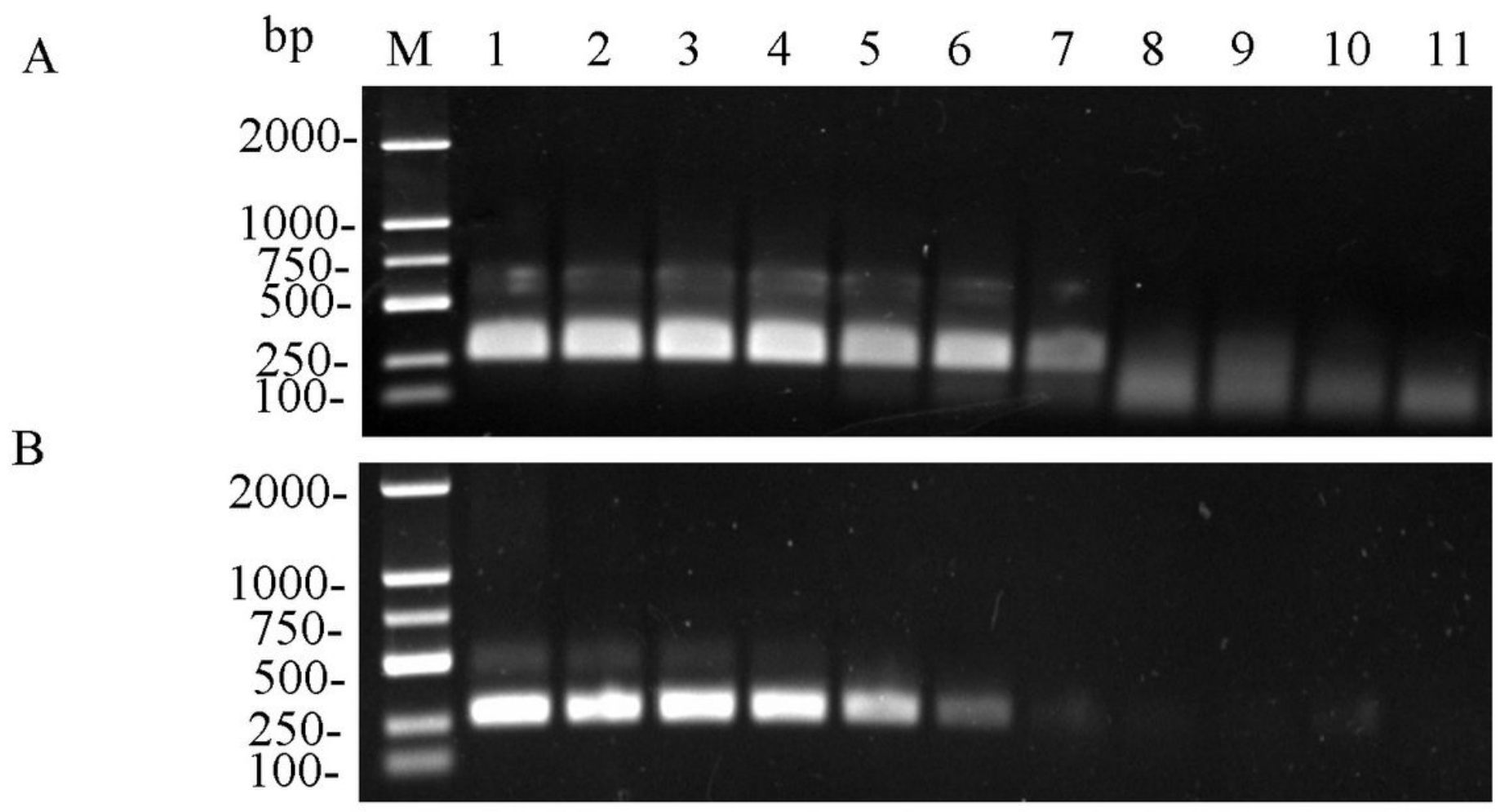

Figure 6

Sensitivity detection of RPA. A: Using RPA assay. B: Using PCR assay. Lane M, Trans2K DNA marker; lanes 1-10, a series of dilutions of plasmid DNAs with concentrations of 109, 108, 107, 106, 105, 104, 103, 102,101 , and 100 copies/ $\mu \mathrm{L}$, respectively; lane 11, ddH2O.

A

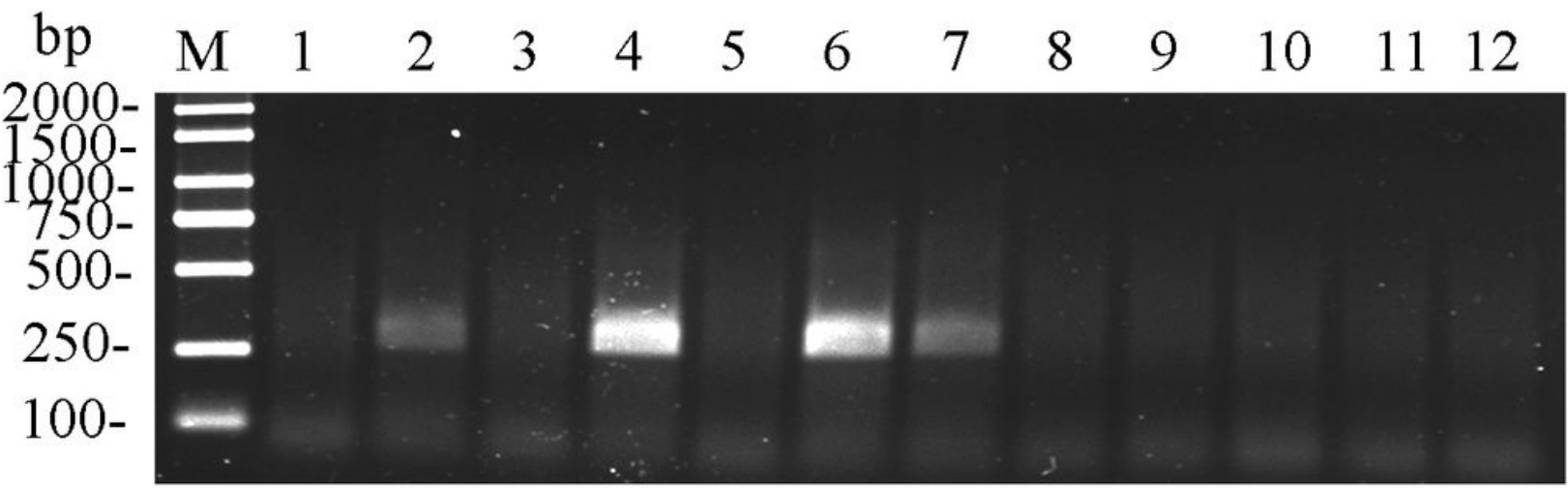

B

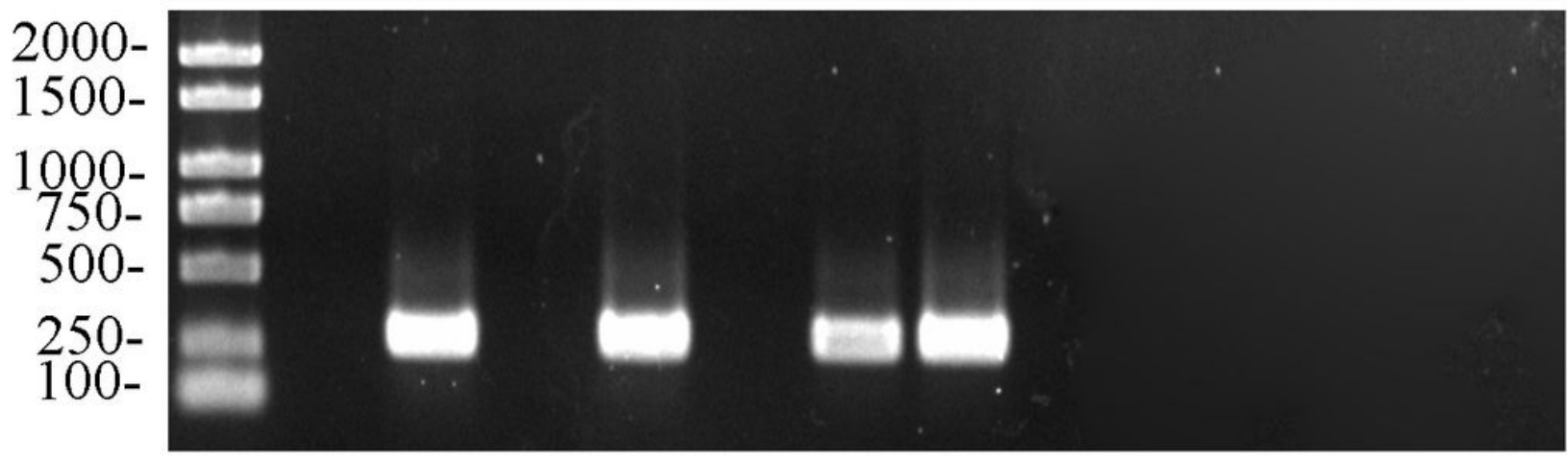




\section{Figure 7}

Application of RPA assay for TSWV detection in field-collected samples. A: Using RPA assay. B: Using RTPCR assay. Lane M, DL2000 Plus DNA marker; lane 1, healthy pepper plants; lane 2, pepper plants infected with TSWV-LNTL; lanes 3-6, pepper leaf samples in field; lane 7, peanut leaf samples in field; lanes 8-12, tomato leaf samples in field.

\section{Supplementary Files}

This is a list of supplementary files associated with this preprint. Click to download.

- SupplementaryTable1.xIsx 